\title{
Screening for cervical dysplasia and reproductive tract infections among coffee plantation workers in Kodagu District, Karnataka, India
}

\section{Abstract:}

Background: Cervical dysplasia is a pre malignant condition and cervical cancer is a leading cause of death among women in developing countries. This study was undertaken to coffee plantation workers to assess the prevalence of cervical dysplasia and reproductive tract infections (RTI) and its associated ethological factors among women aged 40 years and above. Methods: It was a cross sectional study conducted among female plantation workers aged 40 years and above and employed in coffee estates in Kodagu District, Karnataka, India. The tools in this study included an interview schedule to help collect socio demographic details and the procedures included per vaginal and per speculum examination along with Pap smear test. Results: A total of 141 women aged 40 years and above were screened for cervical dysplasia and reproductive tract infections. The prevalence of cervical dysplasia on Pap smear was seven percent and that of RTI was $12.05 \%$. In this study there was no statistically significant association between cervical dysplasia or RTI with socio demographic variables like age, education, per capita income, age at marriage, age at first pregnancy or number of children. Conclusion: The prevalence of cervical dysplasia on Pap smear was seven percent and that of RTI was $12.05 \%$. Regular screening of women in the reproductive age group with Pap smear and prevention and treatment of both partners with RTI may help reduce the chances of developing cervical cancer.

Key Words: Cervical dysplasia, cervical cancer, Pap smear, reproductive tract infections, coffee plantation workers.

\section{Introduction}

Cancer of uterine cervix is the most common malignancy among women in India, and the sixth most common in developed countries.[1] India accounts for about $20 \%$ of cancer cervix reported from the world.[2] It is one of the leading causes of mortality among women in India accounting for $23.3 \%$ of all cancer deaths.[3] The age adjusted incidence rate for cervical cancer has been reported to vary from 19 to 44/100 000 women in various cancer registries in India.[4] The predominant risk factor for cervical cancer is persistent infection with a high-risk oncogenic type of Human papilloma virus (HPV) (types 16, 18, $31,33,35,42,55,58)$. Malignant transformation by HPV is influenced by several factors such as HPV virus type, co-infection with multiple oncogenic virus types and high viral load. Host factors like parity, early age of sexual activity, poor socio-economic status and sexual promiscuity are important contributory factors.[5] Fortunately, the natural history of cervical cancer is such that it is possible to detect it early during a

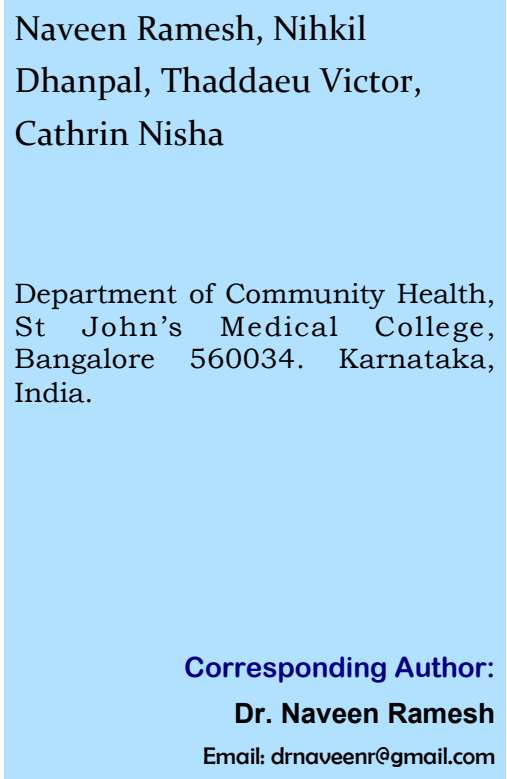

Corresponding Author: Dr. Naveen Ramesh Email: drnaveenr@gmail.com

C인 2014 IJOSH All rights reserved. pre-invasive curable stage by screening and early intervention, thereby preventing progression into a life threatening illness.[6] Despite this fact, almost three fourth of the cases are diagnosed in the advanced stages of disease.[2] The proportion of women living in communities who undergo Pap smear tests ranges from $2.6-6.9 \%$ in India.[7-10] Various methods of screening available include Papanicolaou smear (cytological screening), Visual inspection method using acetic acid (VIA) and Lugol's iodine (VILI) and HPV - DNA testing.[11] However, it is well established in literature and clinical practice that the best method for early detection and screening of precancerous lesions of uterine cervix is cytological examination by Pap smear.[12] Pap smear method with sensitivity of $72 \%$ and specificity of $94 \%$ is suitable for population based screening programme.[13] The present study was conducted with the aim of assessing the prevalence of cervical dysplasia and reproductive tract infections and its associated factors among unscreened population of female coffee plantation workers currently/ever married women aged 40 years and above. 


\section{Methods}

A cross sectional study was conducted among non-pregnant female plantation workers aged 40 years and above in three coffee estates located in Virajpet Taluk, Kodak District, Karnataka, India from March - May 2011. Ethical approval was obtained and all the eligible women were recruited and explained about the study including the procedure and an informed consent was obtained. Data was collected using an interview schedule which included socio demographic data, family planning arrangements and general health status. The gynecological examination included a thorough inspection of the external genitalia, speculum examination to check for the presence of vaginal discharge and the appearance of the cervix. A sterile endo-cervical swab and a high vaginal swab were used to collect vaginal secretions for microscopy examination. A Papanicolaou (Pap) smear was collected with disposable wooden Ayers spatula. The smears were prepared on glass slides and then fixed with ethanol based fixative and transported within 48 hours for reporting to an accredited pathology laboratory in Mysore. The microscopic examination included gram stain and potassium hydroxide wet mount.

\section{Results}

Total of 141 women gave consent and were underwent screening. The mean age was $46.79 \pm 5.77$ years. The mean age at marriage was 17.4 years and $97(68.8 \%)$ of the subjects were married before completing 18 years of age (legal age of marriage for females in India). The socio demographic details of the study population have been explained in Table I.

Table I: Socio demographic details of the study population

\begin{tabular}{|c|c|c|c|}
\hline Variable & Interval & Number & Percentage \\
\hline \multirow{5}{*}{ Age in years } & $40-45$ & 66 & 46.8 \\
\hline & $46-50$ & 40 & 28.4 \\
\hline & $51-55$ & 23 & 16.3 \\
\hline & $56-60$ & 11 & 7.8 \\
\hline & $61-65$ & 1 & 0.7 \\
\hline \multirow{4}{*}{ Education } & Illiterate & 111 & 78.7 \\
\hline & Class 1-4 & 13 & 9.3 \\
\hline & Class 5-7 & 15 & 10.6 \\
\hline & Class8-10 & 2 & 1.4 \\
\hline \multirow{3}{*}{$\begin{array}{l}\text { Per capita Income } \\
\text { In Rupees }\end{array}$} & $<845$ & 96 & 68.1 \\
\hline & $846-1690$ & 44 & 31.2 \\
\hline & $1690-2818$ & 1 & 0.7 \\
\hline \multirow[b]{2}{*}{ Marital status } & Currently married & 103 & 73 \\
\hline & $\begin{array}{l}\text { Divorced/ } \\
\text { widowed }\end{array}$ & 38 & 27 \\
\hline \multirow{3}{*}{$\begin{array}{c}\text { Age at Marriage in } \\
\text { years }\end{array}$} & $<15$ & 48 & 34 \\
\hline & $16-18$ & 49 & 34.8 \\
\hline & $>18$ & 44 & 31.2 \\
\hline
\end{tabular}

Table II depicts the gynecological examination findings of the study population. In the study population, 97 (68.8\%) had normal findings on speculum examination.

Table II: Per vaginal findings of the study population

\begin{tabular}{|ccc|}
\hline Findings & Number & Percentage \\
\hline Normal & 97 & 68.8 \\
\hline White discharge & 18 & 12.8 \\
\hline Erosions/growth & 11 & 7.8 \\
\hline Bleeding /on touch & 11 & 7.8 \\
\hline $2^{\text {nd }}$ Degree prolapse or more & 4 & 2.8 \\
\hline
\end{tabular}

Table III explains the association between socio demographic variables and Pap smear findings. There was no statistically significant association between socio demographic features like age, education and per capita income with Pap smear findings.

Table III: Association between socio demography and Pap smear findings

\begin{tabular}{|c|c|c|c|c|c|c|}
\hline \multirow{2}{*}{\multicolumn{2}{|c|}{ Variable }} & \multicolumn{4}{|c|}{$\begin{array}{l}\text { Pap Smear Findings } \\
\text { Number (\%) }\end{array}$} & \multirow{3}{*}{$\begin{array}{c}\text { Total } \\
66 \\
(46.8)\end{array}$} \\
\hline & & Normal & $\begin{array}{l}\text { Inflamma- } \\
\text { tory Smear }\end{array}$ & Dysplasia & $\begin{array}{l}\text { Infec- } \\
\text { tion }\end{array}$ & \\
\hline \multirow{4}{*}{ Age } & $40-45$ & $6(9.1)$ & $42(63.6)$ & $5(7.6)$ & $\begin{array}{c}13 \\
(19.7)\end{array}$ & \\
\hline & $46-50$ & $6(15.0)$ & $30(75.0)$ & $2(5.0)$ & $2(5.0)$ & $\begin{array}{c}40 \\
(28.4)\end{array}$ \\
\hline & $51-55$ & $4(17.4)$ & $16(69.6)$ & $2(8.7)$ & $1(4.3)$ & $\begin{array}{c}23 \\
(16.3)\end{array}$ \\
\hline & $56-60$ & $3(25)$ & $7(58.3)$ & $1(8.3)$ & $1(8.3)$ & $12(8.5)$ \\
\hline \multirow{3}{*}{ Education } & $\begin{array}{l}\text { Illit- } \\
\text { erate }\end{array}$ & $\begin{array}{c}15 \\
(13.5)\end{array}$ & 74 (66.7) & $8(7.2)$ & $\begin{array}{c}14 \\
(12.6)\end{array}$ & $\begin{array}{c}111 \\
(78.7)\end{array}$ \\
\hline & $\begin{array}{c}\text { Class } \\
1-4\end{array}$ & $2(15.4)$ & $10(76.9)$ & 0 & $1(7.7)$ & $13(9.2)$ \\
\hline & $\begin{array}{l}\text { Class } \\
5-10\end{array}$ & $2(11.8)$ & $11(64.7)$ & $2(11.8)$ & $\begin{array}{c}2 \\
(11.8)\end{array}$ & $\begin{array}{c}17 \\
(12.1)\end{array}$ \\
\hline \multirow{3}{*}{$\begin{array}{c}\text { Per capita } \\
\text { income in } \\
\text { Rupees }\end{array}$} & $<846$ & $\begin{array}{c}13 \\
(13.5)\end{array}$ & $66(68.8)$ & $5(5.2)$ & $\begin{array}{c}12 \\
(12.5)\end{array}$ & $\begin{array}{c}96 \\
(68.6)\end{array}$ \\
\hline & $\begin{array}{l}846- \\
1690\end{array}$ & 5 (11.6) & $29(67.4)$ & $5(11.6)$ & $4(9.3)$ & $\begin{array}{c}43 \\
(30.7)\end{array}$ \\
\hline & $\begin{array}{l}1690- \\
2818\end{array}$ & $\begin{array}{c}1 \\
(100.0)\end{array}$ & 0 & 0 & 0 & $1(0.7)$ \\
\hline
\end{tabular}

Table IV depicts the association between reproductive variables and Pap smear findings. There was no statistically significant association between reproductive variables like age at marriage, age at first pregnancy, abortions, number of children and Pap smear findings. Among the study population 117 (83\%) had ever practiced any form of birth control and 24 (17\%) did not practice any form of birth control.

\section{Discussion}

In the study population (46.8\%) of the women were in the age group of $40-45$ years. Of all $78.7 \%$ of them were illiterate. 
Table IV: Association between reproductive variables and Pap smear findings

\begin{tabular}{|c|c|c|c|c|c|c|}
\hline \multirow{2}{*}{\multicolumn{2}{|c|}{ Variable }} & \multicolumn{4}{|c|}{ Pap Smear Findings } & \multirow{2}{*}{ Total } \\
\hline & & \multirow{2}{*}{$\begin{array}{l}\text { Normal } \\
4(8.3)\end{array}$} & \multirow{2}{*}{$\begin{array}{c}\text { Inflammatory } \\
\text { smear } \\
34(70.8)\end{array}$} & \multirow{2}{*}{$\begin{array}{l}\text { Dysplasia } \\
2(4.2)\end{array}$} & \multirow{2}{*}{$\begin{array}{l}\text { Infection } \\
8(16.7)\end{array}$} & \\
\hline \multirow{3}{*}{$\begin{array}{c}\text { Age at marriage in } \\
\text { years }\end{array}$} & $<15$ & & & & & $48(34.0)$ \\
\hline & $16-18$ & $8(16.3)$ & $29(59.2)$ & $4(8.2)$ & $8(16.3)$ & $49(34.8)$ \\
\hline & $>18$ & $7(15.9)$ & $32(72.7)$ & $4(9.1)$ & $1(2.3)$ & $44(31.2)$ \\
\hline \multirow{4}{*}{$\begin{array}{c}\text { Age at } 1^{\text {st }} \text { pregnan- } \\
\text { cy in years }\end{array}$} & $<15$ & $1(5.9)$ & $9(52.9)$ & $1(5.9)$ & $6(35.3)$ & $17(12.4)$ \\
\hline & $16-18$ & $9(18.4)$ & $32(65.3)$ & $3(6.1)$ & $5(10.2)$ & $49(35.8)$ \\
\hline & $>18$ & $8(11.6)$ & $51(73.9)$ & $6(8.7)$ & $4(5.8)$ & $69(50.4)$ \\
\hline & Not known & 0 & $2(100)$ & 0 & 0 & $2(1.5)$ \\
\hline \multirow{2}{*}{ Abortion } & Present & $1(3.3)$ & $23(76.7)$ & $3(10)$ & $3(10)$ & $30(21.3)$ \\
\hline & absent & $18(16.2)$ & $72(64.9)$ & $7(6.3)$ & $14(12.6)$ & $111(78.7)$ \\
\hline \multirow{2}{*}{ Number of children } & $<2$ & $6(9.8)$ & $39(63.9)$ & $8(13.1)$ & $8(13.1)$ & $61(44.5)$ \\
\hline & $>2$ & $12(15.8)$ & $55(72.4)$ & $2(2.6)$ & $7(9.2)$ & $76(55.5)$ \\
\hline
\end{tabular}

Most $(68.8 \%)$ of the women had per capita income less than 846 rupees per month. It was observed that $55.5 \%$ of women had more than two children. Of all $68.8 \%$ had married before 18 years of age which is a potential risk factor for cervical cancer. On gynecological examination $68.8 \%$ had normal cervical findings, $12.8 \%$ had white discharge, $7.8 \%$ had erosions/growths, $7.8 \%$ had bleeding on touch and $2.8 \%$ had second degree cervical prolapse or more. Another study conducted in different setting had showed cervical erosion (22\%), cervicitis $(13.1 \%)$ and vaginitis $(8.4 \%)$ which is higher than our findings [14]. It was found that seven percent of the women had dysplastic smears which were comparable to similar study[15] and lower when compared to another study where the prevalence was $12.7 \%$ [16] probably attributable to lack of promiscuity and isolation of plantation workers. Prevalence of Reproductive tract infections such as trichomoniasis, candiaiasis and anaerobic vaginosis was found to be $12.1 \%$ which was low when compared to another study (24.4\%).[15] The proportion of women having inflammatory smears was $67.3 \%$ may be attributable to undiagnosed subclinical gonococcal or Chlamydia infection or benign glandular changes in the ectocervix. Among risk factors associated with uterine cervix cancer among women, age at marriage less than 18 years $(68.8 \%)$, illiteracy leading to poor genital hygiene $(78.7 \%)$ and age at first pregnancy $(58.2 \%)$ were observed to be the prominent risk factors even though they were not statistically significant. Other studies have reported a significant association of cancer cervix with the above mentioned risk factors.[17-19] There was no statistically significant association between socio demographic features like age, education and per capita income with Pap smear findings or between reproductive variables like age of marriage, age at first pregnancy, abortions and number of children. Population based descriptive study done in Sikkim also found that there was association between age, education, per capita income, age at marriage and child birth.[20] Hospital based study in North India found an association between prevalence of HPV and education and rural population and no association between prevalence of HPV and age, parity and age of marriage.[21]

\section{Conclusion}

The prevalence of cervical dysplasia in the study population on Pap smear was seven percent and reproductive tract infection was $12.05 \%$. The current prevalence of cervical dysplasia and the presence of potential etiological factors among women plantation workers it would be advisable to recommend regular screening and following-up by Pap smear for all eligible workers. Due to the high prevalence of non-specific inflammation on Pap smear, further evaluation for RTIs and regular follow-of women with inflammatory changes is necessary, because women with inflammatory changes can develop dysplastic changes in the future. With the introduction HPV-DNA kits for screening HPV both among males and females in a sample of urine may change the future of screening for HPV.

\section{References}

1. Louie KS, Sanjose S, Mayaud P. Epidemiology and prevention of human papilloma virus and cervical cancer in sub-Saharan Africa: a comprehensive review. Trop Med Int Health 2009 Oct;14 (10); 1287 -302 .

2. Guidelines for cervical cancer screening. Government of India and WHO Collaborative Program. Available from: http:// www.whoindia.org/LinkFiles/ Cancer_resource_ Guidelines_for_CCSP.pdf . Accessed on 26 Oct 2014.

3. World Health Organization. Globocan Fact Sheets. International Cancer Research. Available from: http://www.globocan.iarc.fr/ factsheet.asp\#WOMEN . Accessed on 26 Oct 2014.

4. National Cancer Registry Programme. Ten year consolidated report of the Hospital Based Cancer Registries. Indian Council of Medical Research; 1984-1993.

5. Rolkin ID. Adolescent coitus and cervical cancer association of related events with increased risks. Cancer Res; 1967 27, 603-17

6. Radha YA, Rege JD, Nalini P, Anita B, NaimuddinScreening for carcinoma cervix in lower socioeconomic class of peri urban community. Health and Popul Persp Issues. 1992, 15, 13-7

7. Swan J, Breen N, Coates RJ, Rimer BK, Lee NC. Progress in cancer screening practices in the United States. Results from the 2000 national health interview survey. Cancer. 2003;97:1528-40.

8. Harry TK, Felicia MS, Ngugen S. A needs assessment of barriers to cervical cancer screening in Vietnamese American health care providers. Californian J Health Promotion. 2006;4:146-56.

9. Gakidou E, Nordhagen S, Obermeyer Z. Coverage of cervical cancer screening in 57 countries: Low average levels and large inequalities. PloS Med. 2008;5:132.

10. Aswathy S, Quereshi MA, Kurian B, Leelamoni K. Cervical cancer screening: Current knowledge and practice among women in a rural population of Kerala, India. Indian J Med Res. 2012 Aug;136: 205-10.

11. Bhatla N, Mukhopadhyay A, Kriplani A, et al. Evaluation of adjunctive tests for cervical cancer screening in low resource settings. Indian J Cancer; 2007,44, 51-5. 


\section{Original Article / IJOSH/ ISSN 2091-0878}

12. Papanicolaou GN, Trut $H$. The diagnostic value of vaginal smears in carcinoma of the uterus. J Obstet Gynecol; 1941,42, 193-205.

13. Coste, Cochand, Priollet B, de Cremaux. Cross-sectional study of conventional Cervical Cancer, Monolayer Cytology and HPV DNA testing for Cervical Cancer Screening.BMJ 2003, $326,733$.

14. Pragya S, Manju R, and Panna L. A Community-based Cervical Cancer Screening Program among Women of Delhi using Camp Approach. Indian J Community Med. Jan 2010; 35(1): 86-88.

15. Shamima $Y$, Anindya M. A cyto-epidemiological study on married women in reproductive age group (15-49 years) regarding reproductive tract infection in a rural community of West Bengal. Indian J Public Health. 2012 Jul-Sep;56(3):204-9.

16. Mhaske M, Jawadekar SJ, Saundale SG. Study of Association of some Risk Factors \& Cervical Dysplasia/Cancer Among Rural women. Nat Jour of Com Medicine, 2011 Jul-Sept; 2 (2) 209-212.

17. Dutta PK, Upadhyay A, Dutta M, Urmil AC, Thergaonkar MP, Ganguly SS. A case control study of cancer cervix patients attending Command Hospital, Pune. Ind J Cancer. 1990;27:1018.

18. Caplash N, Sobti C. Epidemiology of cervical cancer-a case control study on North Indian population. Indian J Cancer. 1999;36:179-85.

19. Prabhakar AK, Menon GR. Age at marriage and cervical cancer incidence. Indian J Cancer. 1995;2:63-8.

20. Chankapa YD, Pal R, Tsering D. Correlates of cervical cancer screening among underserved women. Indian Journal of Cancer . Jan-Mar, 2011; Vol 48(1); 40-6.

21. Aggarwal R, Gupta S, Nijhawan R, Suri V, Kaur A, Bhasin V, Arora SK. Prevalence of high-risk human papillomavirus infections in women with benign cervical cytology: A hospital based study from North India. Indian Journal of Cancer. July-Sep 2006 . Volume 43 (3). 110-16. 